JURNAL ILMIAH KOMPUTERISASI AKUNTANSI, Vol. 14, No. 2, Desember 2021, pp.417 - 427

p-ISSN : 1979-116X (print)

e-ISSN : 2614-8870 (online)

http://journal.stekom.ac.id/index.php/kompak

\title{
Pengaruh Leverage, Intensitas Aset Tetap dan Ukuran Perusahaan Terhadap Agresivitas Pajak
}

Eka Ridho Nur Rochmah', Rachmawati Meita Oktaviani ${ }^{2}$

${ }^{1}$ Fakultas Ekonomika dan Bisnis, Universitas Stikubank Semarang, e-mail: ekaridho18@gmail.com

${ }^{2}$ Fakultas Ekonomika dan Bisnis, Universitas Stikubank Semarang, e-mail: meitarachma@edu.unisbank.ac.id

\begin{tabular}{|c|c|}
\hline ARTICLE INFO & ABSTRACT \\
\hline $\begin{array}{l}\text { Article history: } \\
\text { Received } 30 \text { September } 2021 \\
\text { Received in revised form } 2 \text { November } 2021 \\
\text { Accepted } 10 \text { November } 2021 \\
\text { Available online } 1 \text { Desember } 2021\end{array}$ & $\begin{array}{l}\text { This study aims to determine the effect of leverage, } \\
\text { fixed asset intensity, and firm size on tax } \\
\text { aggressiveness. The population in this study are } \\
\text { manufacturing companies listed on the Indonesia } \\
\text { Stock Exchange (IDX) for the } 2017-2020 \text { period. } \\
\text { The sample of this research was taken using non- } \\
\text { probability sampling method with purposive } \\
\text { sampling technique and certain criteria. The method } \\
\text { used in this research is panel data regression } \\
\text { analysis. The results of this study indicate that } \\
\text { leverage has a significant positive effect on tax } \\
\text { aggressiveness, while the intensity of fixed assets } \\
\text { has no effect on tax aggressiveness, and firm size } \\
\text { has a significant positive effect on tax } \\
\text { aggressiveness. The implications of the results of } \\
\text { this study provide input to companies in making } \\
\text { decisions to minimize the tax burden paid so that } \\
\text { companies can be more aggressive towards taxes. }\end{array}$ \\
\hline
\end{tabular}

Keywords: tax aggressiveness; leverage; fixed asset intensity; company size

\section{Pendahuluan}

Sumber pendapatan terbesar di Indonesia berasal dari penerimaan pajak. Pajak digunakan negara untuk membiayai rumah tangga maupun pembangunan nasional demi kesejahteraan masyarakat. Penerimaan pajak tersebut berasal dari wajib pajak orang pribadi maupun badan, bagi wajib pajak pembayaran pajak merupakan suatu bentuk kontribusi dalam pembangunan nasional. Jumlah pendapatan atau laba bersih yang diterima oleh wajib pajak akan sangat mempengaruhi jumlah pajak yang akan dibayarkan kepada negara (Amalia, 2021).

Menurut UU No. 28 Tahun 2007 pasal 1 ayat (1) tentang Ketentuan Umum dan Tata Cara Perpajakan menyatakan "Pajak adalah kontribusi wajib kepada negara yang terutang oleh orang pribadi atau badan yang bersifat memaksa berdasarkan Undang-Undang dengan tidak mendapatkan imbalan secara langsung dan digunakan untuk keperluan negara bagi kemakmuran rakyat". Realisasi penerimaan pajak belum dilakukan secara maksimal oleh pemerintah karena banyak wajib pajak yang masih melakukan penghindaran pajak, hal ini dapat dilihat dari data penerimaan pajak selama tahun 2020. Penerimaan pajak harus bisa mencapai tingkat yang maksimal karena hasil penerimaan pajak tersebut akan digunakan untuk pembiayaan di tingkat pusat maupun daerah (Adisamartha \& Noviari, 2015). 
Kasus penghindaran pajak yang terjadi di Indonesia salah satunya adalah kasus yang dilaporkan oleh Lembaga Tax Justice Network pada tanggal 8 Mei 2019, bahwa perusahaan tembakau milik British American Tobacco (BAT) telah melakukan penghindaran pajak di Indonesia melalui PT Bentoel Internasional Investama. Sehingga dampaknya negara mengalami kerugian sebesar US\$ 14 juta per tahun. Laporan tersebut menjelaskan bahwa BAT telah mengalihkan sebagian pendapatannya keluar dari Indonesia melalui cara pinjaman intraperusahaan pada tahun 2013 dan 2015, sehingga mengakibatkan Indonesia kehilangan pendapatan bagi negara sebesar US\$ 11 juta per tahun. Cara lain yang digunakan yaitu melalui pembayaran kembali ke Inggris untuk royalti, ongkos dan layanan dimana Indonesia mengalami kerugian sebesar US\$2,7 juta per tahun (Prima, 2019).

Bagi perusahaan, pajak merupakan beban yang akan mengurangi laba bersih. Ada perbedaan tujuan dari pemerintah yang menginginkan penerimaan pajak yang besar sangat bertolak belakang dengan tujuan dari perusahaan yang menginginkan untuk membayar pajak seminimal mungkin. Pihak pemerintah harus dapat memikirkan suatu cara agar perusahaan dapat membayarkan pajaknya secara optimal sehingga dapat memperoleh penghasilan negara yang progresif dan stabil dari tahun ke tahun. Salah satu tindakan yang dapat digunakan perusahaan untuk meminimalkan beban pajaknya yaitu dengan cara perencanaan pajak (tax planning), penghindaran pajak (tax avoidance) ataupun Agresivitas Pajak (Leksono et al., 2019).

Frank et al., (2009) menjelaskan bahwa agresivitas pajak merupakan suatu tindakan untuk memanipulasi penghasilan kena pajak yang dirancang dengan melakukan tindakan perencanaan pajak (tax planning) guna meminimalkan beban pajak baik secara legal (tax avoidance) maupun secara ilegal (tax evasion). Namun banyak celah yang digunakan untuk meminimalkan beban pajak atau melakukan penghematan pajak yang semakin besar, sehingga perusahaan tersebut dianggap semakin agresif juga terhadap pajak (Nurhayati et al., 2018).

Agresivitas pajak dapat dipengaruhi oleh beberapa faktor, faktor yang utama yaitu leverage. Leverage merupakan suatu rasio yang menunjukkan besarnya utang perusahaan guna membiayai kegiatan operasional. Perusahaan yang memiliki hutang akan mendapatkan intensif pajak berupa potongan atas bunga pinjaman. Potongan bunga pinjaman inilah yang sering dimanfaatkan perusahaan untuk mengurangi beban pajak penghasilan (Wulansari et al., 2020). Hasil penelitian yang dilakukan oleh (Wulansari et al., 2020) menyatakan bahwa leverage berpengaruh negatif signifikan terhadap agresivitas pajak. Namun berbeda dengan hasil penelitian yang dilakukan oleh (Amalia, 2021) yang menyatakan bahwa leverage memiliki pengaruh positif signifikan terhadap agresivitas pajak.

Faktor selanjutnya yang mempengaruhi agresivitas pajak yaitu, intensitas aset tetap. Intensitas aset tetap merupakan suatu perbandingan antara intensitas kepemilikan aset tetap dengan total aset tetap yang dimiliki oleh perusahaan. Aset tetap yang dimaksud yaitu aset tetap yang diperoleh dalam bentuk siap pakai yang digunakan untuk operasional perusahaan dan tidak dijual. Setiap aset tetap pasti akan memiliki beban depresiasi yang berfungsi sebagai pengurang pajak. Oleh karena itu, suatu kepemilikan aset tetap yang tinggi akan menghasilkan beban depresiasi yang tinggi pula, sehingga akan mengakibatkan laba perusahaan berkurang. Hasil penelitian yang dilakukan oleh (Wulansari et al., 2020) menunjukkan hasil bahwa intensitas aset tetap berpengaruh negatif signifikan. Namun hasil penelitian lain menunjukkan bahwa intensitas aset tetap tidak berpengaruh terhadap agresivitas pajak penelitian ini dilakukan oleh (Savitri \& Rahmawati, 2017).

Faktor yang mempengaruhi agresivitas pajak yang terakhir yaitu ukuran perusahaan. Ukuran perusahaan dapat menggambarkan besar atau kecilnya suatu perusahaan yang dinilai dari total aset perusahaan. Perusahaan yang memiliki total aset yang besar menandakan bahwa perusahaan tersebut relatif besar. Sehingga hal tersebut juga akan mempengaruhi pendapatan suatu perusahaan dimana perusahaan yang besar akan lebih banyak melakukan agresivitas pajak (Wulansari et al., 2020). Hal ini juga sejalan dengan hasil penelitian yang dilakukan oleh (Wahyuni, 2018) yang menunjukkan hasil bahwa ukuran perusahaan berpengaruh positif

JURNAL ILMIAH KOMPUTERISASI AKUNTANSI Vol. 14, No. 2, Desember 2021 : 417 - 427 
signifikan. Namun berbeda dengan hasil penelitian yang dilakukan oleh (Wulansari et al., 2020) yang menunjukkan hasil bahwa ukuran perusahaan berpengaruh negatif signifikan.

Jensen \& Meckling, (1976), menyebutkan bahwa teori agensi adalah hubungan antara satu principal dan satu agen. Principal maupun agen tersebut berorientasi pada utility maximizer. Kondisi tersebut berarti bahwa agen sebagai pengelola perusahaan dapat bertindak untuk memenuhi kepentingan pribadinya. Hal ini berlawanan dengan kepentingan principal yang berusaha untuk memaksimalkan pengembalian atas sumber dayanya, sehingga hubungan ini memicu adanya perbedaan kepentingan antara pemilik perusahaan dengan manager yang menyebabkan ketidakefisien informasi yang diperoleh keduanya. Perbedaan kepentingan antara principle dan agent dapat mempengaruhi berbagai hal yang berkaitan dengan kinerja perusahaan, salah satunya adalah kebijakan perusahaan mengenai pajak perusahaan.

Frank et al., (2009) menyebutkan bahwa agresivitas pajak merupakan suatu tindakan untuk memanipulasi pendapatan kena pajak yang dirancang dengan melakukan tindakan perencanaan pajak (tax planning) guna meminimalkan beban pajak baik secara legal (tax avoidance) maupun secara ilegal (tax evasion). Namun banyak celah yang digunakan untuk meminimalkan beban pajak atau melakukan penghematan pajak yang semakin besar, sehingga perusahaan tersebut dianggap semakin agresif juga terhadap pajak (Nurhayati et al., 2018). Tindakan agresivitas pajak dilakukan oleh perusahaan karena perusahaan ingin meminimalkan beban pajak yang bertujuan untuk memaksimalkan nilai perusahaan.

Salah satu cara untuk mengetahui bahwa perusahaan tersebut melakukan agresivitas pajak atau tidak yaitu menggunakan skala pengukuran proksi Effective Tax Rate (ETR). Berdasarkan proksi pengukuran tersebut, suatu perusahaan dapat dikatakan melakukan agresivitas pajak apabila memiliki nilai ETR yang mendekati nol, sehingga apabila semakin rendah nilai ETR maka semakin tinggi pula tingkat agresivitas pajak yang dilakukan oleh perusahaan.

Leverage dapat menggambarkan suatu keadaan perusahaan melalui pemenuhan kewajiban jangka panjang. Leverage timbul karena perusahaan membiayai aset dengan hutang yang disertai dengan beban bunga. Dengan adanya beban bunga tersebut dapat mengurangi penghasilan kena pajak (deductible expense) karena beban bunga dapat mengurangi laba yang diperoleh oleh perusahaan. Apabila perusahaan memiliki hutang yang tinggi maka beban bunga yang dihasilkan juga akan semakin besar sehingga perusahaan akan semakin agresif terhadap pajak. Oleh karena itu, perusahaan sengaja menambah hutang yang tinggi agar mendapatkan suatu keuntungan dari beban bunga tersebut (Savitri \& Rahmawati, 2017). Hal ini juga diperkuat oleh hasil penelitian (Amalia, 2021; Pratiwi \& Oktaviani, 2021) yang menunjukkan bahwa leverage berpengaruh positif signifikan terhadap agresivitas pajak.

Intensitas aset tetap yang dimiliki oleh suatu perusahaan dapat menggambarkan seberapa besar investasi aset tetap yang dilakukan oleh perusahaan. Kepemilikan aset tetap tersebut menunjukkan bahwa seberapa banyak kekayaan yang dimiliki oleh perusahaan, karena apabila semakin besar investasi aset tetap yang dilakukan oleh perusahaan maka akan semakin besar pula beban depresiasi yang ditanggung oleh perusahaan (Pratiwi \& Oktaviani, 2021). Beban depresiasi tersebutlah yang akan menyebabkan laba kena pajak juga akan semaki berkurang. Oleh karena itu perusahaan akan memilih menggunakan dana yang menganggur untuk diinvestasikan ke aset tetap agar dapat mengurangi beban kena pajak, sehingga perusahaan akan semakin agresif terhadap pajak yang akan dibayarkan oleh perusahaan (Amalia, 2021). Hal ini juga diperkuat oleh hasil penelitian yang dilakukan (Siahaan, 2020; Wahyuni, 2018) yang menyatakan bahwa intensitas aset tetap berpengaruh positif sigifikan terhadap agresivitas pajak.

Ukuran perusahaan dapat dinilai berdasarkan banyaknya total aset yang dimiliki oleh perusahaan. Apabila aset yang dimiliki perusahaan besar maka semakin besar pula ukuran perusahaan tersebut (Leksono et al., 2019). Ukuran perusahaan akan mempengaruhi perusahaan dalam membayar pajak karena besar atau kecilnya perusahaan akan menunjukkan pendapatan

Pengaruh Leverage, Intensitas Aset Tetap dan Ukuran Perusahaan Terhadap Agresivitas Pajak (Eka Ridho Nur Rochmah) 
yang diterima oleh perusahaan tersebut. Sehingga apabila perusahaan semakin besar maka perusahaan tersebut juga dinilai semakin agresif terhadap pajak. Hal ini sejalan dengan penelitian (Allo et al., 2021; Yanti \& Hartono, 2019) yang menjelaskan bahwa ukuran perusahaan berpengaruh positif signifikan terhadap agresivitas pajak.

Berdasarkan penelitian terdahulu dan pengembangan hipotesis untuk menjelaskan suatu hubungan variabel dependen dan variabel independen, maka kerangka penelitian dapat dijelaskan dalam gambar sebagai berikut :

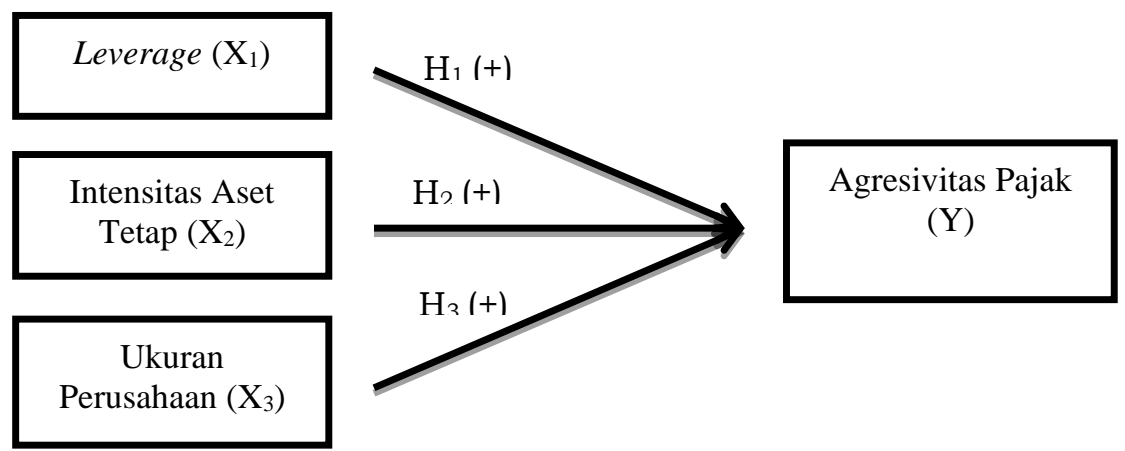

Gambar 1. Kerangka Penelitian

Hipotesis yang diuji dalam penelitian ini adalah :

$\mathrm{H}_{1}$ : Leverage berpengaruh positif signifikan terhadap agresivitas pajak

$\mathrm{H}_{2}$ : Intensitas aset tetap berpengaruh positif signifikan terhadap agresivitas pajak

$\mathrm{H}_{3}$ : Ukuran perusahaan berpengaruh positif signifikan terhadap agresivitas pajak

\section{Metode Penelitian}

Variabel yang digunakan dalam penelitian ini adalah variabel agresivitas pajak sebagai variabel dependen dan variabel leverage, intensitas aset tetap dan ukuran perusahaan sebagai variabel independen. Berikut proksi pengukuran pada masing-masing variabel :

Dalam penelitian ini, agresivitas pajak diukur dengan menggunakan Effective Tax Rate (ETR) yang diharapkan agar dapat mengathui seberapa besar keagresifan dalam perencanaan pajak yang dilakukan oleh perusahaan.

$$
E T R=\frac{\text { Total beban sebelum pajak }}{\text { Laba sebelum pajak }}
$$

Leverage memberikan perbedaan antara total utang perusahaan dengan total aset yang dimiliki oleh perusahaan. Leverage dalam penelitian ini menggunakan Debt to Asset Ratio (DAR).

$$
\text { DAR }=\frac{\text { Total liabilitas }}{\text { Total aset }}
$$

Pada penelitian ini, intensitas aset tetap diukur dengan total aset tetap dibagi dengan total aset, karena intensitas aset tetap menggambarkan investasi yang dilakukan perusahaan dalam bentuk aset tetap.

$$
\text { LAT }=\frac{\text { Total Aset Tetap }}{\text { Total aset }}
$$

Ukuran perusahaan menunjukkan besar atau kecilnya perusahaan yang diukur dengan total aset. Pada penelitian ini diukur menggunakan logaritma naturan total aset yang dimiliki oleh perusahaan.

$$
S I Z E=\operatorname{Ln}(\text { Total aset })
$$




\section{Objek Penelitian, Unit Sampel, Populasi dan Penentuan Sampel}

Penelitian ini menggunakan pendekatan kuantitatif dengan menggunakan data sekunder, yang berupa laporan keuangan atau annual report. Dimana populasi dalam penelitian ini adalah perusahaan manufaktur yang terdaftar di Bursa Efek Indonesia (BEI) periode 2017-2020. Sumber data laporan keuangan tersebut diperoleh melalui website www.idx.co.id. Teknik pemilihan sampel menggunakan metode non-probability sampling yaitu teknik purposive sampling yang bertujuan untuk mendapatkan sampel yang sesuai dengan kriteria dan tujuan yang diinginkan oleh peneliti. Dimana kriteria untuk pengambilan sampel ini yaitu sebagai berikut (1) perusahaan manufaktur yang terdaftar di Bursa Efek Indonesia Periode 2017-2020 (2) laporan keuangan yang menggunakan satuan mata uang rupiah (3) perusahaan yang mengalami laba berturut-turut selama periode 2017-2020 (4) perusahaan yang melaporkan laporan keuangannya selama periode penelitian dan sudah di audit (5) perusahaan yang memiliki nilai ETR $<1$.

\section{Hasil dan Pembahasan}

Pemilihan sampel menggunakan Teknik Purposive Sampling sesuai dengan kriteria yang sudah ditentukan, sehingga dapat diperoleh sampel sebanyak 208 dengan rincian sebagai berikut :

Tabel 1. Kriteria Sampel

\begin{tabular}{clc}
\hline No & \multicolumn{1}{c}{ Kriteria } & Jumlah \\
\hline 1. & Perusahaan manufaktur yang terdaftar di BEI periode 2017-2020 & 146 \\
2. & $\begin{array}{l}\text { Laporan keuangan yang disajikan dalam satuan dolar } \\
\text { 3. }\end{array}$ & $\begin{array}{l}\text { Laporan keuangan yang mengalami kerugian selama periode } \\
\text { penelitian }\end{array}$ \\
4. & $\begin{array}{l}\text { Perusahaan yang tidak melaporkan laporan keuangan selama } \\
\text { periode 2017-2020 }\end{array}$ & $(14)$ \\
5. & Perusahaan yang memiliki nilai ETR>1 & $(4)$ \\
\hline & Jumlah perusahaan yang terpilih sebagai sampel penelitian & $\mathbf{5 2}$ \\
\hline
\end{tabular}

Pengaruh Leverage, Intensitas Aset Tetap dan Ukuran Perusahaan Terhadap Agresivitas Pajak 
3.1 Statistik Deskriptif

Pengujian statistik deskriptif dilakukan untuk menjelaskan mengenai nilai minimum, nilai maksimum, nilai rata-rata, dan standar deviasi dari masing-masing variabel. Berikut hasil pengujian statistik deskriptif pada masing-masing variabel :

Tabel 2. Statistik Deskriptif

\begin{tabular}{lcccc}
\hline & ETR & DAR & IAT & SIZE \\
\hline Mean & 0.278221 & 0.380529 & 0.475192 & 22.04341 \\
Median & 0.250000 & 0.360000 & 0.495000 & 21.78500 \\
Maximum & 2.480000 & 0.780000 & 0.810000 & 25.82000 \\
Minimum & 0.010000 & 0.080000 & 0.090000 & 18.89000 \\
Std. Dev. & 0.194455 & 0.180959 & 0.161697 & 1.496830 \\
Skewness & 7.520886 & 0.184974 & -0.127156 & 0.388924 \\
Kurtosis & 81.50429 & 1.942419 & 2.464288 & 2.506055 \\
& & & & \\
Jarque-Bera & 55372.89 & 10.87961 & 3.047731 & 7.358248 \\
Probability & 0.000000 & 0.004340 & 0.217868 & 0.025245 \\
& & & & \\
Sum & 57.87000 & 79.15000 & 98.84000 & 4585.030 \\
Sum Sq. Dev. & 7.827242 & 6.778442 & 5.412192 & 463.7833 \\
& & & & \\
Observations & 208 & 208 & 208 & 208 \\
Cross sections & 52 & 52 & 52 & 52 \\
\hline
\end{tabular}

Berdasarkan hasil pengujian statistik deskriptif diatas, nilai rata-rata pada agresivitas pajak menunjukkan hasil sebesar 0,27 , nilai maksimum sebesar 2,48 , dan nilai minimum sebesar 0,01 . Sedangkan untuk nilai standar deviasi pada agresivitas pajak menunjukkan sebesar 0,19 . Hasil pengujian pada variabel leverage memiliki nilai rata-rata sebesar 0,38 , nilai maksimum sebesar 0,78 , dan nilai minimum sebesar 0,08 . Sedangkan untuk nilai standar deviasi memiliki nilai sebesar 0,18 .

Pada variabel intensitas aset tetap menunjukkan nilai rata-rata sebesar 0,47 , nilai maksimum sebesar 0,81, dan untuk nilai minimum sebesar 0,09. Sedangkan nilai standar deviasi sebesar 0,16 . Selanjutnya pada variabel ukuran perusahaan memiliki nilai rata-rata sebesar 22,04, niali maksimum sebesar 25,82, dan nilai minimum sebesar 18,89. Sedangkan untuk nilai standar deviasi pada variabel ukuran perusahaan menunjukkan sebesar 1,49

\subsection{Uji Chow}

Regresi data panel dapat dilakukan dengan tiga model, yaitu Common Effect Model (CEM), Fixed Effect Model (FEM), dan Random Effect Model (REM). Masing-masing model tersebut memiliki kekurangan dan kelebihan tersendiri. Pemilihan model tersebut dapat dilihat berdasarkan hasil uji chow dan hasil uji hausman. Pengujian uji chow ini menunjukkan hasil :

Tabel 3. Hasil Uji Chow

\begin{tabular}{lrrr}
\hline Redundant Fixed Effects Tests & & & \\
$\begin{array}{l}\text { Pool: Untitled } \\
\text { Test cross-section fixed effects }\end{array}$ & & & \\
\hline Effects Test & Statistic & d.f. & Prob. \\
\hline & & & \\
Cross-section F & 1.453494 & $(51,153)$ & 0.0429 \\
Cross-section Chi-square & 82.175959 & 51 & 0.0037 \\
\hline
\end{tabular}

JURNAL ILMIAH KOMPUTERISASI AKUNTANSI Vol. 14, No. 2, Desember 2021: $417-427$ 
Berdasarkan hasil uji chow tersebut, nilai prob menunjukkan sebesar $0,0429<0,05$ yang artinya model terbaik yang dapat digunakan adalah fixed effect model (CEM), sehingga model tersebut harus diujikan kembali dengan menggunakan uji hausman untuk mengetahui model mana yang terbaik antara model uji fixed effect model (FEM) atau random effect model (REM).

\subsection{Uji Hausman}

Setelah mengetahui hasil uji chow yang menunjukkan model fixed effect model (FEM) yang terbaik, selanjutnya dilakukan uji hausman untuk mengetahui model yang akan digunakan, uji hausman ini menunjukkan hasil :

Tabel 4. Hasil Uji Hausman

Correlated Random Effects - Hausman Test

Pool: Untitled

Test cross-section random effects

\begin{tabular}{lccc}
\hline Test Summary & $\begin{array}{c}\text { Chi-Sq. } \\
\text { Statistic }\end{array}$ & Chi-Sq. d.f. & Prob. \\
\hline Cross-section random & & & \\
\hline
\end{tabular}

Hasil uji hausman diatas, menunjukkan bahwa nilai prob 0,2239>0,05 sehingga model terbaik yang digunakan yaitu random effect model (REM). Dengan hasil uji REM ini dapat diketahui pengaruh antara variabel leverage, intensitas aset tetap, dan ukuran perusahaan terhadap agresivitas pajak berdasarkan uji koefisien determinasi, uji F, dan uji T. Pengujian random effect model (REM) diperoleh hasil sebagai berikut :

Dependent Variable: ETR

Tabel 5. Hasil Uji REM

Method: Pooled EGLS (Cross-section random effects)

Date: 10/18/21 Time: 19:22

Sample: 20172020

Included observations: 4

Cross-sections included: 52

Total pool (balanced) observations: 208

Swamy and Arora estimator of component variances

\begin{tabular}{|c|c|c|c|c|}
\hline Variable & Coefficient & Std. Error & t-Statistic & Prob. \\
\hline $\mathrm{C}$ & 0.147333 & 0.228248 & 0.645498 & 0.5193 \\
\hline DAR & 0.055235 & 0.086169 & 6.401008 & 0.0422 \\
\hline IAT & 0.079072 & 0.097159 & 0.813840 & 0.4167 \\
\hline SIZE & 0.003280 & 0.010786 & 5.304053 & 0.0139 \\
\hline \multicolumn{5}{|c|}{ Weighted Statistics } \\
\hline R-squared & 0.027942 & \multirow{5}{*}{\multicolumn{2}{|c|}{$\begin{array}{l}\text { Mean dependent var } \\
\text { S.D. dependent var } \\
\text { Sum squared resid } \\
\text { Durbin-Watson stat }\end{array}$}} & 0.231018 \\
\hline Adjusted R-squared & 0.210664 & & & 0.184427 \\
\hline S.E. of regression & 0.185039 & & & 6.984827 \\
\hline F-statistic & 5.404427 & & & 2.285744 \\
\hline $\operatorname{Prob}(F-$-statistic) & 0.026437 & & & \\
\hline
\end{tabular}

Pengaruh Leverage, Intensitas Aset Tetap dan Ukuran Perusahaan Terhadap Agresivitas Pajak 
Berdasarkan hasil uji random effect model (REM) tersebut dapt diketahui bahwa nilai Adjusted R-squared sebesar 0,210664 yang artinya bahwa variabel leverage, intensitas aset tetap, dan ukuran perusahaan memiliki kontribusi terhadap agresivitas pajak sebesar $21,06 \%$ sedangkan sisanya sebesar 78,94\% dapat dijelaskan oleh variabel lain yang tidak diteliti pada penelitian ini. Nilai F hitung 5,404427>F tabel 2,794 atau nilai prob (F-statistic) sebesar 0,026437<0,05 yang berarti menunjukkan bahwa $\mathrm{H}_{1}, \mathrm{H}_{2}$, dan $\mathrm{H}_{3}$ diterima sedangkan $\mathrm{H}_{0}$ ditolak yang artinya semua variabel secara simultan semua variabel berpengaruh positif signifikan terhadap agresivitas pajak.

\section{Pengaruh leverage terhadap agresivitas pajajk}

Hasil pengujian hipotesis $1\left(\mathrm{H}_{1}\right)$ menunjukkan bahwa variabel leverage memiliki nilai koefisien sebesar 0,055235 dengan nilai t hitung sebesar 6,401008> t tabel 2,011 dan nilai signifikansinya sebesar 0,0422<0,05 sehingga $\mathrm{H}_{0}$ ditolak dan $\mathrm{H}_{1}$ diterima. Artinya terdapat pengaruh positif signifikan antara leverage terhadap agresivitas pajak. Apabila dikaitkan dengan teori agensi, maka perusahaan yang memiliki jumlah hutang yang tinggi akan menimbulkan biaya bunga juga tinggi Biaya bunga tersebutlah yang menjadi beban sehingga dapat dimanfaatkan oleh perusahaan untuk mengurangi laba kena pajak, dan beban pajak yang dibayarkan oleh perusahaan juga akan berkurang. Semakin besar leverage yang dimiliki oleh perusaahaan, maka agresivitas pajak yang dilakukan oleh perusahaan juga akan semakin tinggi. Penelitian ini sejalan dengan (Amalia, 2021; Pratiwi \& Oktaviani, 2021; Putri et al., 2019) yang menyatakan bahwa leverage berpengaruh positif signifikan terhadap agresivitas pajak. Namun penelitian ini tidak sejalan dengan (Savitri \& Rahmawati, 2017; Wulansari et al., 2020) yang menyatakan leverage berpengaruh negatif signifikan terhadap agresivitas pajak.

\section{Pengaruh intensitas aset tetap terhadap agresivitas pajak}

Berdasarkan hasil pengujian hipotesis $2\left(\mathrm{H}_{2}\right)$ menunjukkan bahwa nilai koefisien pada variabel intensitas aset tetap sebesar 0.079072 dengan nilai $t$ hitung $0.813840<\mathrm{t}$ tabel 2,011 sedangkan nilai signifikansinya sebesar $0.4167>0,05$ sehingga $\mathrm{H}_{0}$ diterima dan $\mathrm{H}_{2}$ ditolak. Hal tersebut berarti bahwa tidak terdapat pengaruh antara intensitas aset tetap terhadap agresivitas pajak. Jika intensitas aset tetap dikaitkan dengan teori agensi, perusahaan yang memiliki aset tetap menunjukkan kekayaan suatu perusahaan tersebut. Apabila semakin besar aset tetap yang diinvestasikan oleh perusahaan maka akan semakin besar pula beban depresiasi yang ditanggung oleh perusahaan. Beban depresiasi tersebutlah yang dapat mengurangi laba sehingga perusahaan memanfaatkan beban tersebut untuk mengurangi jumlah pajak yang dibayarkan oleh perusahaan. Namun dalam penelitian ini, intensitas aset tetap tidak berpengaruh terhadap agresivitas pajak sehingga perusahaan yang memiliki aset tetap tinggi dapat dinilai tidak agresif terhadap pajak yang dibayarkan karena perusahaan tidak mampu memaksimalkan beban depresiasi tersebut. Hasil penelitian ini sejalan dengan penelitian yang dilakukan oleh (Amalia, 2021; Pratiwi \& Oktaviani, 2021; Savitri \& Rahmawati, 2017) yang menyatakan bahwa intensitas aset tetap tidak berpengaruh terhadap agresivitas pajak. Namun penelitian ini berbeda dengan hasil penelitian yang dilakukan oleh (Muliawati \& Karyada, 2020; Siahaan, 2020; Wahyuni, 2018) yang menyatakan bahwa intensitas aset tetap berpengaruh positif signifikan terhadap agresivitas pajak.

\section{Pengaruh ukuran perusahaan terhadap agresivitas pajak}

Berdasarkan hasil pengujian hipotesis $3\left(\mathrm{H}_{3}\right)$ menunjukkan bahwa ukuran perusahaan memiliki nilai koefisien sebesar 0.003280 dengan nilai t hitung 5.304053>t tabel 2,011 sedangkan nilai signifikansinya sebesar $0.0139<0,05$ sehingga $\mathrm{H}_{0}$ ditolak dan $\mathrm{H}_{3}$ diterima. Hal ini berarti bahwa terdapat pengaruh positif signifikan terhadap agresivitas pajak. Apabila ukuran perusahaan dikaitkan dengan teori agensi, maka perusahaan yang memiliki jumlah aset yang besar dapat menunjukkan bahwa perusahaan tersebut juga akan semakin baik dalam pengelolaan aset suatu perusahaan dan memiliki kinerja yang baik pula. Perusahaan yang memiliki aset yang besar dapat

JURNAL ILMIAH KOMPUTERISASI AKUNTANSI Vol. 14, No. 2, Desember $2021: 417-427$ 
meningkatkan laba perusahaan, sehingga investor dapat tertarik untuk berinvestasi di perusahaan tersebut. Sehingga apabila semakin besar ukuran perusahaan maka perusahaan tersebut akan semakin agresif terhadap pajak karena perusahaan dinilai semakin stabil dalam kemampuan untuk mengelola aktivitasnya. Hal ini sejalan dengan penelitian yang dilakukan oleh (Allo et al., 2021; Yanti \& Hartono, 2019) yang menyatakan bahwa ukuran perusahaan berpengaruh positif signifikan terhadap agresivitas pajak. Namun penelitian ini tidak sejalan dengan penelitian yang dilakukan oleh (Widyari \& Rasmini, 2019; Wulansari et al., 2020) yang menyatakan bahwa ukuran perusahaan berpengaruh negatif signifikan terhadap agresivitas pajak.

\section{Kesimpulan} berikut :

Berdasarkan hasil penelitan yang telah dilakukan maka dapat ditarik kesimpulan sebagai

1. Leverage berpengaruh positif signifikan terhadap agresivitas pajak. Apabila semakin besar hutang yang dimiliki oleh perusahaan maka akan semakin besar pula beban bunga yang akan dibayarkan oleh perusahaan. Hal tersebut dapat membuat perusahaan semakin agresif terhadap pajak sehingga agresivitas pajaknya juga akan semakin tinggi.

2. Intensitas aset tetap tidak berpengaruh terhadap agresivitas pajak, hal ini dikarenakan meskipun investasi aset tetap yang dilakukan oleh perusahaan tinggi, namun perusahaan tidak dapat memaksimalkan beban depresiasi yang melekat pada aset tetap tersebut untuk mengurangi beban pajak yang dibayarkan oleh perusahaan.

3. Ukuran perusahaan berpengaruh positif signifikan terhadap agresivitas pajak. Perusahaan yang besar akan menunjukkan bahwa perusahaan tersebut semakin baik dalam kinerja pengelolaan aset, sehingga laba perusahaan akan meningkat pula dan dapat menarik investor untuk melakukan investasi. Apabila semakin besar ukuran perusahaan maka akan semakin agresif juga perusahaan dalam membayarkan pajaknya.

Namun penelitian ini juga menunjukkan bahwa leverage, intensitas aset tetap, dan ukuran perusahaan secara simultan berpengaruh terhadap agresivitas pajak. Implikasi dari hasil penelitian ini dapat memberikan masukan kepada perusahaan dalam mengambil keputusan untuk meminimalisir beban pajak yang akan dibayarkan sehingga perusahaan dapat lebih agresif terhadap pajak. Namun perusahaan tidak terbatas dalam menggunakan variabel leverage dan ukuran perusahaan saja, oleh karena itu untuk penelitian selanjutnya diharapkan menambah atau menggunakan variabel bebas lainnya yang memungkinkan keterkaitan yang lebih besar terhadap agresivitas pajak. Selain itu, penelitian selanjutnya juga dapat menambah periode penelitian yang lebih panjang. 


\section{References}

Adisamartha, I. B. P. F., \& Noviari, N. (2015). Pengaruh Likuiditas, Leverage, Intensitas Persediaan Dan Intensitas Aset Tetap Pada Tingkat Agresivitas Wajib Pajak Badan. EJurnal Akuntansi, 13(3), 973-1000.

Allo, M. R., Alexander, S. W., Suwetja, I. G., Alexander, S. W., \& Suwetja, I. G. (2021). Pengaruh Likuiditas Dan Ukuran Perusahaan Terhadap Agresivitas Pajak (Studi Empiris Pada Perusahaan Manufaktur Yang Terdaftar Di Bei Tahun 2016-2018). Jurnal EMBA: Jurnal Riset Ekonomi, Manajemen, Bisnis Dan Akuntansi, 9(1), 647-657. https://doi.org/10.35794/emba.v9i1.32434

Amalia, D. (2021). Pengaruh Likuiditas, Leverage Dan Intensitas Aset Terhadap Agresivitas Pajak. KRISNA: Kumpulan Riset Akuntansi, 12(2), 232-240. https://doi.org/10.22225/kr.12.2.1596.232-240

Frank, M. M., Lynch, L. J., \& Rego, S. O. (2009). Tax Reporting Aggressiveness and Its Relation to Aggressive Financial Reporting. The Accounting Review, 84(2), 467-496.

Jensen, M. C., \& Meckling, W. H. (1976). Theory of The Firm: Managerial Behavior, Agency Costs and Ownership Structure. Journal of Financial Economics, 3, 305-360.

Leksono, A. W., Albertus, S. S., \& Vhalery, R. (2019). Pengaruh Ukuran Perusahaan dan Profitabilitas terhadap Agresivitas Pajak pada Perusahaan Manufaktur yang Listing di BEI Periode Tahun 2013-2017. JABE (Journal of Applied Business and Economic), 5(4), 301. https://doi.org/10.30998/jabe.v5i4.4174

Muliawati, I. A. P. Y., \& Karyada, I. P. F. (2020). Pengaruh Leverage dan Capital Intensity terhadap Agresivitas Pajak dengan Komisaris Independen Sebagai Variabel Pemoderasi (Studi pada Perusahaan Manufaktur Sektor Industry Barang dan Konsumsi yang Terdaftar di Bursa Efek Indonesia Periode 2016-2018). Hita Akuntansi Dan Keuangan, 2016, 16-31. http://dx.doi.org/10.26623/slsi.v18i2.2301

Nurhayati, Indrawati, N., \& A, A. A. (2018). "Pengaruh Leverage, Capital Intensity Ratio dan Manajemen Laba Terhadap Agresivitas Pajak Perusahaan (Studi Empiris Pada Perusahaan Manufaktur yang Terdaftar di Bursa Efek Indonesia Tahun 2014-2016)." Jurnal Ekonomi, Vol. 26(No. 3), Hal. 128-146. Universitas Riau.

Pratiwi, Y. E., \& Oktaviani, R. M. (2021). Perspektif Leverage, Capital Intensity, dan Manajemen Laba Terhadap Tax Agreesiveness. Jurnal Akuntansi Dan Pajak, 22(1). https://doi.org/10.29040/jap.v22i1.2475

Prima, B. (2019). Tax Justice laporkan Bentoel lakukan penghindaran pajak, Indonesia rugi US\$ 14 juta. Kontan.Co.Id. https://nasional.kontan.co.id/news/tax-justice-laporkan-bentoellakukan-penghindaran-pajak-indonesia-rugi-rp-14-juta

Putri, putu yudha asteris, Dewi, gusti ayu ratih permata, \& Diah, P. diah putri idawati. (2019). Penguruh Kualitas Audit dan Leverage pada Agresivitas Pajak pada Perusahaan Manufaktur yang Terdafardi Bursa Eefek Indonesia Tahun 2013 - 2017 Pengaruh Kualitas Audit Dan Leverage Pada Agresivitas Pajak Pada Perusahaan Manufaktur Yang Terdaftar Di Bursa. Jurnal KRISNA : Kumpulan Riset Akuntansi, 10(2), 148-160.

Savitri, D. A., \& Rahmawati, I. N. (2017). Pengaruh Leverage, Intensitas Persediaan, Intensitas Aset Tetap, Dan Profitabilitas Terhadap Agresivitas Pajak. 8(November), 64-79.

Siahaan, P. S. O. (2020). Profitabilitas, Leverage , Capital Intensity Pengaruhnya Terhadap Agresivitas Pajak. Jurnal Penelitian Akuntansi, 2(April), 146-152.

Tiaras, I., \& Wijaya, H. (2017). Pengaruh Likuiditas, Leverage, Manajemen Laba, Komisaris Independen Dan Ukuran Perusahaan Terhadap Agresivitas Pajak. Jurnal Akuntansi, 19(3), 380. https://doi.org/10.24912/ja.v19i3.87

Wahyuni, E. F. N. (2018). Pengaruh Komisaris Independen, Leverage, Intensitas Persediaan, Intensitas Aset Tetap Dan Ukuran Perusahaan Terhadap Agresivitas Pajak Pada Wajib Pajak Badan. Jom Feb, 1(1), 1-15.

Widyari, N. Y. A., \& Rasmini, N. K. (2019). Pengaruh Kualitas Audit, Size, Leverage, dan

JURNAL ILMIAH KOMPUTERISASI AKUNTANSI Vol. 14, No. 2, Desember 2021 : 417 - 427 
Kepemilikan Keluarga pada Agresivitas Pajak. E-Jurnal Akuntansi, 27, 388. https://doi.org/10.24843/eja.2019.v27.i01.p15

Wulansari, T. A., Titisari, K. H., \& Nurlaela, S. (2020). Pengaruh Leverage, Intensitas Persediaan, Aset Tetap, Ukuran Perusahaan, Komisaris Independen Terhadap Agresivitas Pajak. Jae (Jurnal Akuntansi Dan Ekonomi), 5(1), 69-76. https://doi.org/10.29407/jae.v5i1.14141

Yanti, L. D., \& Hartono, L. (2019). Effect of Leverage, Profitability and Company Size on Tax Aggressiveness. ECo-Fin, 1(1), 1-11. 